ISSN 2414-1143

Научный альманах стран Причерноморья. 2017. Том 12. № 4

DOI 10.23947/2414-1143-2017-12-4-42-47

UDC 329

\title{
KURDISH PROBLEM IN POLITICAL LIFE OF MODERN TURKEY
}

\author{
Khazan Yalyn \\ Istanbul, Turkish Republic \\ science-almanac@mail.ru
}

In this article author argues that the AKP is not a classical political party, but an economic enterprise (cartel) and an ideological organization based on political Islam. These two properties allow us to assume with a high degree of probability what actions the AKP and Erdogan may take in order to remain in power, and also provide an opportunity to make sound forecasts of the political situation in Turkey for the near future.In the first years of its rule, the AKP created a new layer of monopoly bourgeoisie closely connected with Western monopolies, which has exploited all the means of the state apparatus. The AKP itself was an organic component of this layer, which was organized as a consortium led by Erdogan himself and his cohort. The ideological goals of the AKP, based on political Islam, allowed them to establish a strong social basis for the newly created regime. They eliminated internal competition, for instance by appointing the party's co-founder Abdullah Gul president in 2007, a role that was largely ceremonial at the time. Thus the AKP turned itself into a Bonapartist dictatorship. This dictatorship was consolidated in an informal coalition with the Gulenists, even in a power-sharing, giving them whole apparatus of judiciary and police. The current popular opinion among the politicians is that Erdogan is going to turn away from the traditional pro-American position that has been followed by all Turkish governments since the 1950s. However, this opinion does not coincide with reality. Firstly, the AKP as an economic enterprise and as the state itself is bound up through umbilical cord with imperialism and it has to act in line with the interests of the new class it represents. Secondly, AKP is ideologically an American project. This project, namely political islam, nowhere, and, especially not in Turkey will be able to free itself from this proAmericanism because of historical and ideological reasons. And because of practical ones: The US and the EU, as it is appeared in the lawsuit against Zarrab in New York, have a lot of trumps in the game against AKP and Erdogan, and Erdogan has almost nothing. The results of this process will be manifested in the Kurdish problem. The USA has transformed the Kurdish nationalist movement into its collaborator one, and it relies on the Kurds to legitimize its illegal presence in Syria. The Erdogan regime is currently in a de-facto coalition with the "traditional" Turkish fascist movement (MHP - Nationalist Movement Party) to oppose the Kurdish national demands and even their right to exist as a people. But this policy cannot last forever. Erdogan's government, allegedly rejecting any concessions on the Kurdish issue, should indeed find out a way of reconciliation with the Kurdish nationalist movement in the sense of common pro-Americanism.

Key words: AKP, Kurdish problem, Turkey, USA, coalition.

\section{[Хазан Ялын Курдская проблема в политической жизни современной Турции]}

Рассматривается политическая, идеологическая и экономическая основа режима Эрдогана в Турции, и утверждается, что АКП - это не классическая политическая партия, но экономическое предприятие (картель), а также идеологическая организация, основанная на политическом исламе. Эти два свойства позволяют нам с большой долей вероятности предполагать, какие действия будут предпринимать АКП и Эрдоган, чтобы оставаться во власти, а также дают возможность сделать обоснованные прогнозы развития политической ситуации в Турции на ближайшее время. В первые годы своего правления АКП создала новый слой монополистической буржуазии, тесно связанный с западными монополиями, который использовал и использует все возможности государства. Этот слой организован как консорциум, во главе которого стоит сам Эрдоган и близкие ему люди. Идеологические цели АКП (политический ислам) обеспечивали ей возможность консолидации крепкого массового базиса нового созданного режима. Вследствие этого, власть АКП превратилась в бонапартистскую диктатуру, избавившись от сооснователя АКП Абдуллаха Гюля отправив его на пост президента Турецкой 
республики в 2007 г. Эта диктатура была консолидирована в неофициальной коалиции с гюленистами. Современное распространенное мнение среди политиков заключается в том, что Эрдоган собирается свернуть с традиционной коллаборационистской линии, которой следовали все правительства Турции с 1950-х гг. Однако это мнение не совпадает с действительностью. Во-первых, АКП как экономическое предприятие и как государство является связанной с империализмом и, естественно, в его действиях проявляются классовые рефлексы того нового класса, который она представляет и которым она сама является. Во-вторых, АКП идеологически является американским проектом, и этот проект, именно политический ислам, нигде, и, особенно в Турции, не сможет освободить себя от про-американизма изза исторических причин. Результаты этого процесса проявятся в курдской проблеме. США сделали курдское националистическое движение коллаборационистским и пытаются легитимизировать свое незаконное присутствие в Сирии, опираясь на него. Режим Эрдогана основан на де-факто коалиции с традиционным фашистским движением, направленным против курдских национальных требований, и даже против самого существования курдского народа. Правительство Эрдогана, отвергающее любые уступки по курдской проблеме, в самом деле должно идти на компромисс с курдским национальным движениям в русле их общего коллаборационизма.

Ключевые слова: АКП, курдская проблема, Турция, США, коалиция.

Khazan Yalyn. Istanbul, Turkish Republic.

Хазан Ялын. е. Стамбул, Турецкая Республика

Undoubtedly, in the Western countries there have been many ministers, prime ministers, presidents were elected and appointed to these posts after spending long years in the management of big monopolies. The most recent examples of this are Macron in France and Trump in the USA. However, undoubtedly, occupying these positions, they have all been held accountable to maintain a neutral position of the state in relation to monopolies. That is, there are checks and balances to ensure that they do not use their political powers to the benefit of some group over the others. But Erdogan's example points to an absolutely exceptional position and an exceptional tendency. For the first time in the modern history of the Turkish Republic, a political leader does not have any limits to use his political powers to provide economic advantages for himself and his family, but directly manages the huge cartel. Apparently at least since 2005, the year in which Erdogan began to consolidate his power, a number of firms, some of which belong to his family, have operated as a part of this cartel, and the state itself is being reorganized in order to continue this process uninterruptedly. Traditional capitalist groups are also forced to cooperate with Erdogan's cartel via "carrots and sticks" policies.

The AKP (the ruling Justice and Development Party of Turkey), as Erdogan's personal property and the main body for achieving political and economic goals of political islamists, is not a classical political party. It is simultaneously an economic enterprise, i.e. a cartel. This cartel is in a close relationship with the imperialist monopolies, and cannot break its ties with them. Subsequently, the cartel of AKP will take any route it thinks necessary when it suspects that disintegration is a near threat. The AKP is an American project. Undoubtedly, any project might turn against its creators. But the AKP is a project of political islam; it is not only a cartel, but also an ideological organization. As an organization based on the ideological foundation of political islam, it came to power and remained there for many years thanks to the clear support of the United States. Political islam as an American project cannot die as long as an anti-American movement in the Arab and Muslim world remains valid, that is, as long as the Arab and Muslim world and the United States exist. Consequently, AKP must rely 
on the imperialist block. On the other hand, the AKP and the United States have collaborated to such a degree in various national and regional affairs that one may now call them accomplices. The problem is that partnership in crime is profitable to the strong party - not only politically and economically, but also in terms of intelligence on its accomplice. Come the judgement day, the strong side may even play the prosecutor. As the USA has several means to blackmail the AKP, whereas the latter does not have anything on the former, it is doomed to capitulate to American requirements.

Having rendered the legal opposition completely ineffective and dysfunctional, the AKP created a one-party system. However, its rule can can be compared to neither socialist, nor petty-bourgeois (such as the kemalist) regimes. It is comparable to the fascist regimes like Mussolini's. The AKP began to create the Bonapartist regime in 2007 with the elimination of Abdullah Gul. The presidency was presented as an award to Gul for allegedly being "secundum inter pares", but it turned out that Erdogan supported his candidacy in order to remove him from power, and to consolidate his own authority. Then he turned this bonapartist regime into a fascist one in alliance with the Gulenist gangsters (yet another sort of allegedly "moderate islamists") from 2011 onwards. The fascist regime was institutionalized with Erdogan's election in 2014, and all power gathered in his hands. The entire state was transformed into a one-party dictatorship like the Mussolini regime, passivating all and especially legal opposition, making the parliament dysfunctional and ruling the country not according to the law, but with executive orders with the power of law, which began to be issued following the military coup attempt in 2016. Moreover, this attempt helped Erdogan to get rid of his Gulenist partners.

What distinguishes the Erdogan regime from the classical fascist regimes is that the relative autonomy of the state has completely expired, and by the fact that all power (economic, political, and ideological) is usurped by the AKP.

The former centers of power have been completely eliminated. The army was cleared of all elements that opposed AKP on the one hand, and found itself in alliance with the AKP cartel through OYAK on the other. ${ }^{1}$ The hierarchical structure of OYAK which used to be independent from government interventions was violated by AKP with the help of the coup attempt. All necessary administrative, educational, and institutional measures were taken to ensure that the army is now recruited from only those social layers that constitute the mass base of the AKP. Consequently, the army lost its military capacity to a large extent. The same measures were taken in the judicial field. All apparatus of the judicial sphere were re-formed by the sole criteria of whether they met the needs of the AKP. All courts, ranging from the trifling to the constitutional, declared their "bay'ah" (pledge of allegiance) to the AKP without hesitation violating the law itself.

At the same time, the AKP began to transform the whole society into an islamic, and indeed, anti-enlightenment community. Erdogan's statement on May 28th this year clearly shows that the AKP has passed the last threshold in Turkey, and now declares that Sharia, though unofficially, must prevail in the whole country: "To have political power is one thing,

1 One peculiar property of Turkey, which distinguishes it from the other countries in terms of the composition of the ruling capitalist groups, is that the army is among them. Established in 1961, the Pension Fund of the Turkish Armed Forces (OYAK) collected funds by deducting 10 percent of the personnel salaries, and became one of the largest conglomerates in Turkey in a short time. OYAK still raises 10 percent contribution share from army members' salaries, and all the officers and non-commissioned-officers are considered shareholders of this holding. 
and to have social and cultural power is another. We have been in power for 14 years. But we still have troubles and difficulties about social and cultural power."

On the other hand, AKP continues to be in a "good fellowship" with islamist terrorist groups on the basis of a common worldview. Even if it would rather not do so, its Islamist policies make this a necessity. This is how, for instance, the An-Nusra Front of al-Qaida declared that it would not enter into armed conflict with Turkish troops sent into the Syrian town of Idlib according to Astana agreement, and even offered to serve them as scouts. ${ }^{2}$

Because of these structural properties, AKP not only prefers or wants, but needs unconditional preservation and continuation of its power. In order to retain its monopoly profits, must deepen the process of unification with the state, construct and violate loose and unstable class alliances in the form of declared or unannounced party coalitions, organize fascist gangs from petty-bourgeois masses, as well as from the masses of the new strata of middle and big bourgeoisie (those second ones already became unsurpassed sovereigns in the bureaucracy and army of the Turkish state). All of them constitutes popular basis of AKP.

No fascist regime can be overthrown by peaceful parliamentarian methods. The fascist regime, such as Third Reich, manifests itself as eternal for two reasons: first, to perpetuate its mass support, it must declare such an ideological-religious mission. Secondly: losing power means losing all possessions, because of the crimes committed by the regime. For the AKP, this means the loss of its whole cartel (if not a total annihilation), and all of its jail-free cards. Consequently, in Turkey, the possibility of replacing the government through peaceful democratic elections has ceased, as the last referendum has shown. But this argument does not mean that there no longer will not be any replacement of governments; although this is very difficult. The point is that the state has been transformed to such an extent that no future government will be able to reverse the process.

AKP has formed an alliance with the traditional fascist movements (MHP) on the basis of hostility to the Kurdish nationality and their legitimate national demands, but this is not stable and solid alliance yet. It shows inclination to disintegrate insofar as it damages the structural properties of AKP (that is, being a fascist movement that relies on the sunnite majority of the society and being a cartel; in both circumstances, the AKP will take any measures it deems necessary to preserve its power).

At least since 2011, the AKP began to directly interfere with regional conflicts because of these structural properties. These interventions were organized, on the one hand, in order to expand the cartel's reach in the Middle East and beyond, and to obtain the greatest possible interests; and on the other hand, in order to take over leadership of the sunni islamist front, which is fighting against the anti-American states in the region. However, countries like Turkey cannot be constructive in the global or regional problems; they are not playmakers, but take advantages of the imperialist policy loopholes. The AKP represented a deviation from the traditional role of such countries in that it not only took advantage of these loopholes, but constantly spoiled the games of others. At first, it had enough powerful means to consolidate that role due to close friendship with islamist terrorists, and thus became not a constructive, but a destructive power to some extent.

2 Their statement reads as follows: "We ought note the reality now, that the Turkish army has requested some positions opposite these atheist factions [the YPG in Afrin] with a limited force under the mujahideen's sway, one that in no circumstance exercises control or can exercise control in these areas in which God's law is supreme. And so the mujahideen's emirs may allow this." https://twitter.com/ZlatkoPercinic/status/918519444581871616 
The AKP succeeded in this, because it was precisely at this time that imperialism went into a deep crisis of hegemony. The main imperialistic destructive political enterprise in the Middle East, so called "Arab spring", and its failure, opened up a vacuum for the AKP to continue this role. Also as a straight consequence of the same process, i.e. the victory over the imperialistic project thanks to the lawful and legitimate intervention of the Russian Federation, caused the AKP a big ideological earthquake and still ongoing aftershocks.

The conclusions of this policy in the Kurdish issue of Turkey are the following:

a) When the AKP clearly realized this shock in the elections of the June 7,2015 , it immediately sought to create an alliance with the traditional fascist movement regarding the Kurdish problem, thus reinforced its dominant political bloc with them.

b) One immediate result of this alliance is the neutralization of the various social layers, which in fact are in opposition against AKP state. That is, the "allergy to the Kurds" of Turkish nationalist masses, and the opposition of kemalist and leftist masses (which no way might support AKP) to the pro-Americanization of the Kurdish nationalist movement, begot in these masses silence towards coalition of islamists and nationalist fascists.

c) Consequently, a new unofficial coalition has been created in place of the shattered coalition with the Gulenists.

d) However, this policy reached to its boundaries with the fact that the PKK (Kurdistan Workers' Party, i.e. Kurdish separatists under the leadership of Ocalan) and its affiliates voluntarily became a voluntary armed force of the United States in Syria. Thus, the possibility of an alliance with Turkish fascists based upon hostility to the Kurds is shrinking, since the continuation of this policy will ultimately lead to a confrontation with the United States. Though there already exists a confrontation, the AKP cannot endure it for a long time because of its structural characteristics.

e) In the view of the author of this article, AKP at the moment is developing new projects to come into the "reform" path again in the Kurdish problem, as it did with the "Kurdish opening'. However, this aspiration has a very intricate course. It is not a secret that the AKP flirted with Barzani, his supporters and islamists in the Peoples' Democratic Party (Halkların Demokratik Partisi) HDP (and in the Kurdish movement in general) for a long time, even when at every opportunity it loudly announced that it would "uncompromisingly continue to fight forever if necessary"; but the attempt to create such an alliance seems to have crashed into the wall because of the hostility between Barzani, and the PKK and affiliates.

f) According to the author, all these developments and the fact that the United States resolutely declares at every opportunity that in the near future it will not abandon his new ally in Syria under any circumstances, will force the AKP to sit at the table of reconciliation with PKK under US mediation US.

g) Two developments will determine the destiny of these negotiations: the first is the future of the anti-imperialist struggle in Syria; and the second (although it seems quite unlikely) is the emergence of a new Kurdish movement that seeks to unite with other nations and nationalities of Turkey other than Kurdish, in line with the traditional principles of leftist movement of Turkey (i.e. anti-imperialism and anti-fascism).

The main desire of all western countries is to ensure the stability of capitalist exploitation in Turkey, and to keep Turkey dependent to the USA and the EU without causing any risks. Erdogan may have become a 'persona non grata' in the West, but the massive support behind him and the stability of his operations make him the best among the worse options in Turkey for them. Undoubtedly, Western countries prefer an Erdogan with extracted teeth. 
Consequently, imperialism cannot and will not abandon him as long as he stays the best among the worse, but it should and will balance his destructive force in such a way as the Zarrab / Halkbank case in the courthouse of New York; it is possible to bring similar lawsuits in the EU countries, too.

The AKP as a political organization and AKP as a cartel can exist only in a imperialist world and under their dominance. The ideology of the AKP can only exist as much as it is a part and continuation of the American project "political Islam". Therefore, the AKP can neither politically nor economically betray the United States. It must fully incorporate with US policies to maintain its power, unless US mercilessly compels Erdogan to capitulate unconditionally, in this case he might take any irrational measure to protect himself even without caring its consequences. 